\title{
Virulence and extended-spectrum $\beta$-lactamase encoding genes in Escherichia coli recovered from chicken meat intended for hospitalized human consumption
}

\author{
Gamal A. Younis ${ }^{1}$, Rasha M. Elkenany ${ }^{1}$, Mohamed A. Fouda ${ }^{2}$ and Noura F. Mostafa ${ }^{2}$
}

1. Department of Bacteriology, Mycology and Immunology, Faculty of Veterinary Medicine, Mansoura University, Egypt;

2. Department of Nutrition, Gastroenterology Surgery Center, Mansoura University, Egypt.

Corresponding author: Rasha M. Elkenany, e-mail: dr_rashavet22@mans.edu.eg

Co-authors: GAY: gamalyounis_1@hotmail.com, MAF: mohamed.raouf999@yahoo.com, NFM: norafathy388@yahoo.com Received: 16-05-2017, Accepted: 26-09-2017, Published online: 28-10-2017

doi: 10.14202/vetworld.2017.1281-1285 How to cite this article: Younis GA, Elkenany RM, Fouda MA, Mostafa NF (2017) Virulence and extended-spectrum $\beta$-lactamase encoding genes in Escherichia coli recovered from chicken meat intended for hospitalized human consumption, Veterinary World, 10(10): 1281-1285.

\begin{abstract}
Aim: This study describes the prevalence of Escherichia coli in frozen chicken meat intended for human consumption with emphasis on their virulence determinants through detection of the virulence genes and recognition of the extended-spectrum $\beta$-lactamase (ESBL) encoding genes ( $b l a_{\mathrm{OXA}}$ and $b l a_{\mathrm{TEM}}$ genes).

Materials and Methods: A total of 120 frozen chicken meat samples were investigated for isolation of $E$. coli. All isolates were subjected to biochemical and serological tests. Eight serotypes isolated from samples were analyzed for the presence of various virulence genes (stx1, stx2, and eae A genes) using multiplex polymerase chain reaction (PCR) technique. Moreover, the strains were evaluated for the ESBL encoding genes ( $b l a_{\mathrm{TEM}}$ and $\left.b l a_{\mathrm{OXA}}\right)$.

Results: Overall, 11.66\% (14/120) chicken meat samples carried E. coli according to cultural and biochemical properties. The most predominant serotypes were O78 and O128: H2 (21.5\%, each), followed by O121: H7 and O44: H18. Molecular method detected that 2 strains $(25 \%)$ harbored stx 1 , 3 strains $(37.5 \%)$ stx 2 , and 3 strains $(37.5 \%)$ both stx 1 and stx2, while $1(12.5 \%)$ strain carried eae A gene. Particularly, only O26 serotype had all tested virulence genes (stx1, stx2, and eae A). The results revealed that all examined 8 serotypes were Shiga toxin-producing E. coli (STEC). The ESBL encoding genes $\left(b l a_{\mathrm{TEM}}\right.$ and $\left.b l a_{\mathrm{OXA}}\right)$ of STEC were detected in $4(50 \%)$ isolates by multiplex PCR. The overall incidence of $b l a_{\mathrm{TEM}}$ and $b l a_{\mathrm{OXA}}$ genes was $3(37.5 \%)$ and $2(25 \%)$ isolates.
\end{abstract}

Conclusion: The present study indicates the prevalence of virulent and ESBL-producing E. coli in frozen chicken meat intended for hospitalized human consumption due to poor hygienic measures and irregular use of antibiotics. Therefore, the basic instructions regarding good hygienic measures should be adapted to limit public health hazard.

Keywords: bla ${ }_{\mathrm{OXA}}$, bla ${ }_{\mathrm{TEM}}$, eaeA, Escherichia coli, extended-spectrum $\beta$-lactamases, stx 1, stx2.

\section{Introduction}

Food represents a possible source of pathogenic- and antibiotic-resistant Escherichia coli strains [1]. Infections due to pathogenic E. coli may be restricted to the mucosal surfaces or distributed throughout the body [2]. Various intestinal and extraintestinal diseases can be caused by $E$. coli isolates harbored virulence genes. Intestinal pathological types are enterotoxigenic E. coli (ETEC), enteropathogenic E. coli (EPEC), enteroaggregative E. coli (EAEC), enteroinvasive E. coli (EIEC), diffusely adherent $E$. coli (DAEC), and Shiga toxin-producing E. coli (STEC). E. coli strains that provide Shiga toxins are called STEC, vero cytotoxin-producing E. coli, or enterohemorrhagic E. coli (EHEC) [3,4]. Mild-tosevere diarrhea and colitis are resulted from strains of

Copyright: Younis, et al. Open Access. This article is distributed under the terms of the Creative Commons Attribution 4.0 International License (http://creativecommons.org/licenses/by/4.0/), which permits unrestricted use, distribution, and reproduction in any medium, provided you give appropriate credit to the original author(s) and the source, provide a link to the Creative Commons license, and indicate if changes were made. The Creative Commons Public Domain Dedication waiver (http://creativecommons.org/ publicdomain/zero/1.0/) applies to the data made available in this article, unless otherwise stated. these pathological types (ETEC, EPEC, EAEC, EIEC, and DAEC) [5]. Whatever, STEC is associated with a wide range of human diseases such as bloody diarrhea, hemorrhagic colitis (HC), and hemolytic-uremic syndrome (HUS) [5]. The Shiga toxins either 1 (stxl) or 2 (stx2) interfere the binding of aminoacyl tRNA to the ribosomes and preventing the protein synthesis resulting in depurinating specific residues of the host cell ribosomes after internalization [6]. The biological activities of stx 1 and stx2, involving cytotoxicity to Vero and HeLa cells, are similar, but the immunological properties are different [7].

The members of $\beta$-lactam antimicrobial agents involve penicillin, cephalosporin, clavams, and cephamycins which have a $\beta$-lactam. The hydrolyzing of $\beta$-lactam ring by $\beta$-lactamases is responsible for the inactivation of $\beta$-lactam antibiotics. The most commonly identified $\beta$-lactamases are TEM-, SHV-, OXA-, CMY-, and CTX-M- $\beta$-lactamases in Gram-negative bacteria [8]. The bla $a_{\mathrm{OXA}}$ gene as antibiotic-resistant gene encodes a carbapenem-hydrolyzing class D-lactamase [9]. The occurrence of infections with extended-spectrum $\beta$-lactamase (ESBL)-producing E. coli in humans is increased as 
a result of intestinal carriage of ESBL-producing bacteria in food animals as well as infectivity of retail meat [10]. Consequently, the transmission of ESBLproducing $E$. coli to humans through consumption of chicken has become a public health hazard [11].

Therefore, the purpose of this study was to investigate the prevalence of $E$. coli and their serotypes in chicken meat intended for hospitalized human consumption with emphasis on their virulence determinants through the finding of virulence factors (stxl, stx2, and eae genes) and recognition of ESBL encoding genes (bla $a_{\mathrm{OXA}}$ and $b l a_{\mathrm{TEM}}$ genes) using multiplex polymerase chain reaction (PCR).

\section{Materials and Methods}

\section{Ethical approval}

In this investigation, we did not use live animals; therefore, ethical approval was not essential. Chicken meat samples were obtained from Gastroenterology Surgery Center (GEC).

\section{Sampling}

A total of 120 frozen chicken meat samples were obtained during October 2015 from GEC, Mansoura University, Egypt. The samples were subjected to bacteriological analysis.

\section{Bacteriological analysis}

A sample of $25 \mathrm{~g}$ from each chicken meat sample was homogenized in $225 \mathrm{ml}$ of bacteriological peptone water and incubated at $37^{\circ} \mathrm{C}$ for $18-24 \mathrm{~h}$. Then, after incubation, $0.1 \mathrm{ml}$ from peptone water was cultured onto MacConkey's agar and Eosin methylene blue (EMB) agar (Oxoid Ltd., England) and incubated at $37^{\circ} \mathrm{C}$ for $24 \mathrm{~h}$. The colonies with pink color on MacConkey's agar and green metallic sheen on EMB agar were considered as E. coli. In addition, it has known that some $E$. coli show purple color with or without metallic sheen on EMB. The following biochemical tests were applied for the identification of suspected colonies: Triple sugar iron agar, citrate utilization, urease production, indole, methyl red, VogesProskauer tests, and motility. The diagnostic E. coli antisera sets (DENKA SEIKEN Co., Japan) were used for serological identification of enteropathogenic types of E. coli isolates depending on $\mathrm{O}$ and $\mathrm{H}$ antigens [12].

\section{Molecular detection of virulence genes and ESBL encoding genes}

Eight different $E$. coli serotypes were used for the detection of virulence factors involving Shiga toxins (stxl and stx2) and intimin (eaeA) genes as well as ESBL-encoding genes $\left(b l a_{\mathrm{TEM}}\right.$ and $\left.b l a_{\mathrm{OXA}}\right)$ by multiplex PCR. DNA extraction was performed using QIA amp kit [13]. The amplification reaction was performed using specific primers and profiles as shown in Tables-1 and 2 [14-16]. The analysis of PCR products was applied by $2 \%$ agarose gel electrophoresis (AppliChem, Germany, GmbH) in 1× TBE buffer stained with ethidium bromide, followed by visualization on an ultraviolet transilluminator.

\section{Results and Discussion}

Food of chicken origin has been a source of virulent and antimicrobial-resistant $E$. coli strains that responsible for a serious public health worldwide causing food poisoning in humans [1]. In this work, $14(11.66 \%)$ of 120 chicken meat samples carried E. coli according to cultural and biochemical properties. This result indicates relatively low prevalence

Table-1: Primer sequences of $E$. coli virulence genes and extended-spectrum $\beta$-lactamase encoding genes.

\begin{tabular}{|c|c|c|c|}
\hline Target gene & Oligonucleotide sequence & Product size (bp) & References \\
\hline stx1 (F) & 5' ACACTGGATGATCTCAGTGG '3 & 614 & {$[14]$} \\
\hline stx1 (R) & 5’ CTGAATCССССТССАТТАTG '3 & & \\
\hline stx2 (F) & 5' CCATGACAACGGACAGCAGTT' '3 & 779 & \\
\hline stx2 (R) & 5' CCTGTCAACTGAGCAGCACTITG '3 & & \\
\hline eaeA (F) & 5’ GTGGCGAATACTGGCGAGACT' '3 & 890 & {$[15]$} \\
\hline eaeA (R) & 5' CСССАТТСТाITСАСCGTCG '3 & & \\
\hline bla ${ }_{\mathrm{OXA}}(\mathrm{F})$ & 5' GGCACCAGATTCAACTITCAAG '3 & 564 & {$[16]$} \\
\hline bla $_{\text {OXA }}(\mathrm{R})$ & 5' GACCCCAAGTITCCTGTAAGTG '3 & & \\
\hline bla ${ }_{\mathrm{TEM}}(\mathrm{F})$ & 5' CATTTCCGTGTCGCCCTTATTC '3 & 800 & \\
\hline$b / a_{\mathrm{TEM}}(\mathrm{R})$ & 5' CGTTCATCCATAGTTGCCTGAC '3 & & \\
\hline
\end{tabular}

Table-2: Cycling conditions of the different primers during PCR.

\begin{tabular}{|c|c|c|c|c|c|}
\hline Target gene & Primary denaturation & Secondary denaturation & Annealing & Extension & Final extension \\
\hline \multirow[t]{2}{*}{ stx1 } & $95^{\circ} \mathrm{C}$ & $95^{\circ} \mathrm{C}$ & $58^{\circ} \mathrm{C}$ & $72^{\circ} \mathrm{C}$ & $72^{\circ} \mathrm{C}$ \\
\hline & $3 \mathrm{~min}$ & $20 \mathrm{~s}$ & $20 \mathrm{~s}$ & $1.5 \mathrm{~min}$ & $5 \mathrm{~min}$ \\
\hline \multirow[t]{2}{*}{ stx2 } & $95^{\circ} \mathrm{C}$ & $95^{\circ} \mathrm{C}$ & $58^{\circ} \mathrm{C}$ & $72^{\circ} \mathrm{C}$ & \\
\hline & $3 \mathrm{~min}$ & $20 \mathrm{~s}$ & $20 \mathrm{~s}$ & $1.5 \mathrm{~min}$ & \\
\hline \multirow[t]{2}{*}{ eaeA } & $95^{\circ} \mathrm{C}$ & $95^{\circ} \mathrm{C}$ & $58^{\circ} \mathrm{C}$ & $72^{\circ} \mathrm{C}$ & \\
\hline & $3 \mathrm{~min}$ & $20 \mathrm{~s}$ & $20 \mathrm{~s}$ & $1.5 \mathrm{~min}$ & \\
\hline \multirow{2}{*}{ bla $_{\mathrm{OXA}}$ and $b / a_{\mathrm{TEM}}$} & $94^{\circ} \mathrm{C}$ & $94^{\circ} \mathrm{C}$ & $61^{\circ} \mathrm{C}$ & $72^{\circ} \mathrm{C}$ & $72^{\circ} \mathrm{C}$ \\
\hline & $10 \mathrm{~min}$ & $30 \mathrm{~s}$ & $35 \mathrm{~s}$ & $1 \mathrm{~min}$ & $1 \mathrm{~min}$ \\
\hline
\end{tabular}

$\mathrm{PCR}=$ Polymerase chain reaction 
rate of $E$. coli in chicken meat intended for human consumption in GEC. A similar observation was recorded by other researchers who detected $11.1 \%$ and $15.8 \%$ of $E$. coli in chicken meat [17,18], respectively. In contrast, Rashid et al. [19], Adeyanju and Ishola [20], and Park et al. [21] found 40\%, 43.4\%, and $75.9 \%$ of $E$. coli in poultry meat, respectively. Whatever, E. coli should be lower than the infective dose in chicken meat, particularly STEC to be considered fit for human consumption. Therefore, the preparation of healthy chicken meat is necessary for public health. However, the contamination of bird carcasses can occur following slaughter and dressing with predominantly enteric bacteria, including E. coli, coming from the skin, hair, feathers, gastrointestinal tract, and the environment at the slaughtering facilities [22].

Serological test of recovered strains identified eight different E. coli serotypes (Table-3). Among identified serotypes, the most predominant serotypes were $\mathrm{O} 78$ and $\mathrm{O} 128 \mathrm{H}$ : $(21.5 \%$, each), followed by O121: H7 and O44: H18 (14.3\%, each) in chicken meat. This result is consistent with the previous study that detected these serotypes in E. coli of avian origin [23]. In addition, our results revealed three subgroups that were EPEC $(7,50 \%)$, followed by EHEC $(4,28.5 \%)$ and $\operatorname{ETEC~}(3,21.5 \%)$. EPEC was the most common subgroup compared to other researchers who detected only $4 \%$ of EPEC in chicken meat [19] and a variable quantity of EPEC [24]. Nearly similar, Momtaz and Jamshidi [25] identified AEEC (34.93\%) and EHEC (21.23\%) subgroups among $E$. coli isolates from chicken meat.

According to multiplex PCR assay, different virulence factors (stx $1, s t \times 2$, and eaeA genes) to eight different serotypes were identified (Table-4) (Figure-1). Overall, $2(25 \%)$ strains harbored stx 1, $3(37.5 \%)$ stx2, and $3(37.5 \%)$ both stx 1 and stx2, while $1(12.5 \%)$ strain carried eae A gene. Particularly, only $\mathrm{O} 26$ serotype had all tested virulence genes (stxl, stx2, and eaeA). From these results, all examined 8 (100\%) serotypes were STEC. In another study, E. coli isolates had stxl $(10.5 \%)$, stx $2(7 \%)$, both stxl and stx2 $(1.5 \%)$, and eaeA $(8 \%)$ virulence genes [19] that were lower than this study. Other investigators detected both stx 1

Table-3: Prevalence and different serotypes of $E$. coli recovered from chicken meat.

\begin{tabular}{lcc}
\hline Serotypes & Number of strains & $\begin{array}{c}\text { Frequency } \\
\text { distribution (\%) }\end{array}$ \\
\hline O44:H18 & 2 & 14.30 \\
O78 & 3 & 21.50 \\
O2:H6 & 1 & 7.10 \\
O153:H2 & 1 & 7.10 \\
Total & 7 & 50 \\
O121:H7 & 2 & 14.30 \\
O91:H21 & 1 & 7.10 \\
O26:H11 & 1 & 7.10 \\
Total & 4 & 28.50 \\
O128:H2 & 3 & 21.50 \\
Overall total & 14 & 11.66 \\
\hline
\end{tabular}

and eae genes in all strains, but no strains had the stx2 [21]. However, other researchers detected the low prevalence of STEC in chicken meat $[1,19]$.

There are serious diseases resulted from STEC strains in humans and animals. The severity of such diseases is related to the type and amount of the produced Shiga toxin [7]. Consequently, the extensive studies have been applied to the type of Shiga toxin formed by STEC recovered from human infections [26]. Besides Shiga toxin virulence genes, Law [7] has detected the eae $A$ gene. In this study, the virulence genes concerning stx 1 , stx 2, and eaeA were detected in E. coli strains recovered from frozen chicken meat. Thus, serious illness such as HUS and HC can occur from the ingestion of raw or undercooked chicken meats in humans.

The multiplex PCR assay is an efficient and rapid method for identification of extended-spectrum $\beta$-lactamase (ESBL) in E. coli isolates. In this work, the ESBL encoding genes $\left(b l a_{\text {TEM }}\right.$ and $\left.b l a_{\text {OXA }}\right)$ of STEC were detected in $4(50 \%)$ isolates by multiplex PCR (Table-4) (Figure-2). Similarly, 49\% of the E. coli isolates were ESBL producers isolated from chicken meat by Mbanga et al. [27]. In contrast, another study reported $94 \%$ of ESBL-producing E. coli isolates recovered from retail meat samples [11]. From these results, the overall occurrence of bla $a_{\text {TEM }}$ and $b l a_{\text {OXA }}$ genes was $3(37.5 \%)$ and $2(25 \%)$ isolates, respectively. There was one isolate harbored both $b l a_{\text {TEM }}$ and $b l a_{\mathrm{OXA}}$ genes. The $b l a_{\mathrm{TEM}}$ gene $(37.5 \%)$ was the predominant one among the isolated strains. The previous studies support our findings that detected $b l a_{\text {TEM }}$ gene as the most recurrent $\beta$-lactamase reliable for $\beta$-lactam resistance $[28,29]$. Furthermore, other investigators

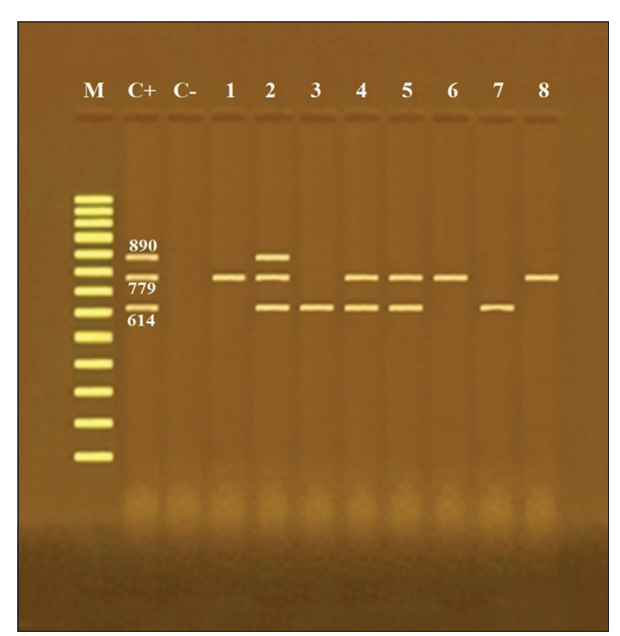

Figure-1: Agarose gel electrophoresis of multiplex polymerase chain reaction of stx1 (614 bp), stx2 (779 bp), and eaeA (890 bp) genes for characterization of different Escherichia coli serotypes. Lane M: 100 bp ladder as molecular size DNA marker, Lane $\mathrm{C}+$ : Control positive E. coli for stx1, stx2, and eaeA genes, Lane C-: Control negative, Lanes $1(\mathrm{O} 2), 6$ (0121), and 8 (0153): Positive E. coli strains for stx2 gene only, Lanes 3 (O44) and 7 (O128): Positive E. coli strains for st 1 gene only, Lane 2 (O26): Positive E. coli strain for stx1, st $x 2$, and eaeA genes, and Lanes 4 (078) and 5 (091): Positive E. coli strains for stx 1 and stx2 genes. 
Table-4: Occurrence of virulence and extended-spectrum $\beta$-lactamase encoding genes in different $E$. coli serotypes recovered from chicken meat.

\begin{tabular}{|c|c|c|c|c|c|c|c|c|}
\hline \multirow[t]{2}{*}{ Sample number } & \multirow[t]{2}{*}{ Serotypes } & \multicolumn{5}{|c|}{ Virulence genes } & \multicolumn{2}{|c|}{$\begin{array}{c}\boldsymbol{\beta} \text {-lactamase } \\
\text { genes }\end{array}$} \\
\hline & & stx 1 & stx 2 & stx 1 and stx 2 & eae $A$ & stx 1 , stx 2 and eae $A$ & $\boldsymbol{b l a}_{\mathrm{TEM}}$ & bla ${ }_{\text {oxA }}$ \\
\hline 1 & $\mathrm{O} 121: \mathrm{H} 7$ & - & + & - & - & - & - & - \\
\hline 2 & $044: \mathrm{H} 18$ & + & - & - & - & - & - & - \\
\hline 3 & 078 & - & - & + & - & - & + & + \\
\hline 4 & $\mathrm{O} 128: \mathrm{H} 2$ & + & - & - & - & - & - & + \\
\hline 5 & O153:H2 & - & + & - & - & - & - & - \\
\hline 6 & $\mathrm{O} 91: \mathrm{H} 21$ & - & - & + & - & - & + & - \\
\hline 7 & $\mathrm{O} 26: \mathrm{H} 11$ & - & - & + & + & + & + & - \\
\hline 8 & $\mathrm{O} 2: \mathrm{H} 6$ & - & + & - & - & - & - & - \\
\hline Total (\%) & 8 & $2(25)$ & $3(37.5)$ & $3(37.5)$ & $1(12.5)$ & $1(12.5)$ & $3(37.5)$ & $2(25)$ \\
\hline
\end{tabular}

Stx 1 = Shiga toxin 1 gene of $E$. coli, Stx2 = Shiga toxin 2 gene of $E$. coli, eae $A=$ Intimin gene of $E$. coli, bla TEM $_{\text {and }}$ $b^{b l a x}{ }_{\text {oxa }}=$ Extended-spectrum $\beta$-lactamase-resistant genes of $E$. coli=Escherichia coli

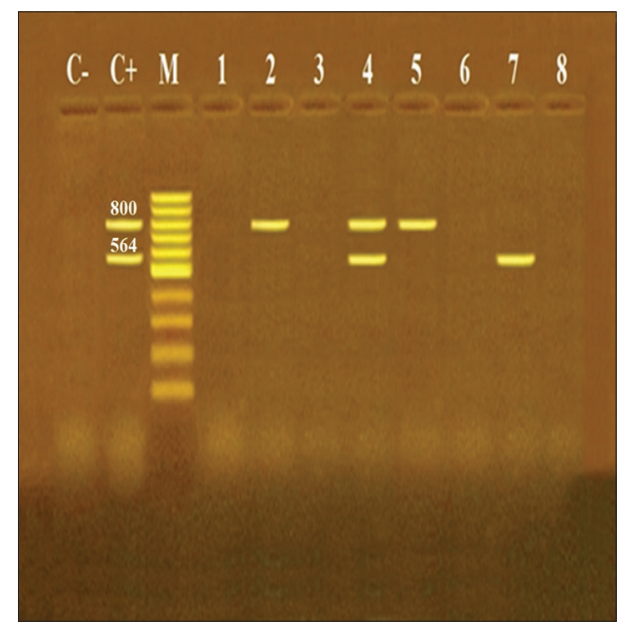

Figure-2: Agarose gel electrophoresis of multiplex polymerase chain reaction of bla ${ }_{\mathrm{OXA}}(564 \mathrm{bp})$ and $\mathrm{bla}_{\mathrm{TEM}}$ (800 bp) as antibiotic resistance genes of different $E$. coli serotypes. Lane M: 100 bp ladder as molecular size DNA marker, Lane $\mathrm{C}+$ : Control positive for $b / a_{\text {TEM }}$ and $b / a_{\text {OXA }}$ genes, Lane C-: Control negative, Lanes 2 (O26) and 5 (091): Positive E. coli strains for bla TEM $_{\text {gen }}$ genly, Lane 7 (O128): Positive E. coli strain for bla ${ }_{\text {OXA }}$ gene only, Lane 4 (078): Positive E.coli strain for both bla ${ }_{\mathrm{OXA}}$ and bla $\mathrm{T}_{\mathrm{TEM}}$ genes, and Lanes 1 (O2), 3 (044), 6 (0121), and 8 (O153): Negative $E$. coli strains for bla ${ }_{\text {OXA }}$ and bla TEM genes.

detected $b l a_{\mathrm{TEM}}$ with the absence of bla $a_{\mathrm{OXA}}$ genes in ESBL-producing isolates from chicken meat [27]. It seems that the irregular use of $\beta$-lactam antibiotics as broad-spectrum antibacterial agents in poultry farms is correlated to the emergence of ESBL-producing isolates in Egypt. Consequently, the isolated STEC strains from chicken meat are a potential reservoir of $\beta$-lactamase genes.

\section{Conclusion}

Frozen chicken meat may be notable hazards to humans because they may carry STEC- and ESBLproducing $E$. coli due to poor hygienic practices. Therefore, it is necessary to improve hygienic measures during the manipulation of meat products to limit public health issue. Furthermore, coordinated measures are essential to decrease or prevent the risks caused by E. coli at different stages in the food chain.
In addition, the problems related to infections by STEC- and ESBL-producing strains can be overcome through appropriate strategy for infection control in hospital settings.

\section{Authors' Contributions}

GAY designed and planned this research work. NFM collected the samples and executed the isolation, biochemical, serological, and molecular characterization work of all isolates. RME and MAF analyzed the data and monitored the isolation, biochemical, serological, and molecular characterization. All authors contributed equally in preparation and revision of the manuscript. All authors read and approved the final manuscript.

\section{Acknowledgments}

The authors are highly thankful to the manager of Gastroenterology Surgery Center, Mansoura University, Egypt, for helping in sample collection. The authors declare that they did not have any funding source or grant to support this research work.

\section{Competing Interests} interests.

The authors declare that they have no competing

\section{References}

1. Trkov, M., Rupel, T., Bertok, D.A., Trontelj, S., Avgutin, G. and Avgutin, J.A. (2014) Molecular Characterization of Escherichia coli strains isolated from different food sources. Food Technol. Biotechnol., 52(2): 255-262.

2. Nataro, J.P. and Kaper, J.B. (1998) Diarrheagenic Escherichia coli. J. Clin. Microbiol. Rev., 11: 132-201.

3. Kaper, J., Nataro, J. and Mobley, H. (2004) Pathogenic Escherichia coli. Nat. Rev. Microbiol., 2: 123-140.

4. Mainil, J. (2013) Escherichia coli virulence factors. Vet. Immunol. Immunopathol., 152: 2-12.

5. Mainil, J.G. and Daube, G. (2005) Verotoxigenic Escherichia coli from animals, humans and foods: Who's who? J. Appl. Microbiol., 98: 1332-1334.

6. Melton-Celsa, A.R. and O'Brien, A.D. (1998) Structure, biology, and relative toxicity of Shiga toxin family members for cells and animals. In: Kaper, J.B. and O'Brien, A.D., editors. Escherichia coli O157:H7 and Other Shiga Toxin-Producing E. coli Strains. American Society or Microbiology, Washington, DC. p121-128. 
7. Law, D. (2000) Virulence factors of Escherichia coli $\mathrm{O} 157$ and other Shiga toxin-producing E. coli. J. Appl. Microbiol., 88: 729-745.

8. Livermore, D.M. and Woodford, N. (2006) The $\beta$-lactamase threat in Enterobacteriaceae, Pseudomonas and Acinetobacter. Trends Microbiol., 14: 413-420.

9. Carrer, A., Poirel, L., Yilmaz, M., Akan, O.A., Feriha, C., Cuzon, G., Matar, G., Honderlick, P. and Nordmann, P. (2010) Spread of OXA-48-encoding plasmid in Turkey and beyond. Antimicrob. Agents Chemother., 54: 1369-1373.

10. Campos, C.B., Fenner, I., Wiese, N., Lensing, C., Christner, M., Rohde, H., Aepfelbacher, M., Fenner, T. and Hentschke, M. (2014) Prevalence and genotypes of extended spectrum beta-lactamases in Enterobacteriaceae isolated from human stool and chicken meat in Hamburg, Germany. Int. J. Med. Microbiol., 304(5-6): 678-684.

11. Hall, M.A.L., Dierikx, C.M., Stuart, J.C, Voets, G.M., Munckhof, M.P., Zandbergen, A.E, Platteel, T., Fluit, A.C., Bruinsma, V.S., Scharinga, J., Bonten, M.G.M., Mevius, D.J. and National ESBL Surveillance Group. (2011) Dutch patients, retail chicken meat and poultry share the same ESBL genes, plasmids and strains. Clin. Microbiol. Infect., 17: 873-880.

12. Kok, T., Worswich, D. and Gowans, E. (1996) Some serological techniques for microbial and viral infections. In: Collee, J., Fraser, A., Marmion, B. and Simmons, A., editors. Practical Medical Microbiology. $14^{\text {th }}$ ed. Churchill Livingstone, UK, Edinburgh.

13. Shah, D., Shringi, S., Besser, T. and Call, D. (2009), In: Liu, D. editors. Molecular Detection of Foodborne Pathogens. Taylor and Francis Group, Florida, USA, CRC Press, Boca Raton. p369-389.

14. Dhanashree, B. and Mallya, S. (2008) Detection of shiga-toxigenic Escherichia coli (STEC) in diarrhoeagenic stool and meat samples in Mangalore, India. Indian J. Med. Res., 128: 271-277.

15. Mazaheri, S., Ahrabi, S. and Aslani, M. (2014) Shiga toxin-producing Escherichia coli isolated from lettuce samples in Tehran, Iran. Jundishapur. J. Microbiol., 7(11): 1-6.

16. Perez, F., Jones, H., Hanson, N. and Geyer, C. (2007) Global challenge of multidrug-resistant Acinetobacter baumannii. Antimicrob. Agents Chemother., 51: 3471-3484.

17. Ukut, I.O., Okonko, I.O., Ikpoh, I.S., Nkang, A.O., Udeze, A.O., Babalola, T.A., Mejeha, O.K. and Fajobi, E.A. (2010) Assessment of bacteriological quality of fresh meats sold in Calabar Metropolis, Nigeria. Electron. J. Environ. Agric. Food Chem., 9(1): 89-100.

18. Momtaz, H., Rahimi, E. and Moshkelani, S. (2012)
Molecular detection of antimicrobial resistance genes in $E$. coli isolated from slaughtered commercial chickens in Iran. Vet. Med., 57(4): 193-197.

19. Rashid, M., Kotwal, S.K., Malik, M.A. and Singh, M. (2013) Prevalence, genetic profile of virulence determinants and multidrug resistance of Escherichia coli isolates from foods of animal origin. Vet. World, 6(3): 139-142.

20. Adeyanju, G.T. and Ishola, O. (2014) Salmonella and E. coli contamination of poultry meat from a processing plant and retail markets in Ibadan, Oyo State, Nigeria. Springerplus, 3: 139 .

21. Park, H.J., Yoon, J.W., Heo, E.J., Ko, E.K., Kim, K.Y., Kim, Y.J., Yoon, H.J., Wee, S.H., Park, Y.H. and Moon, J.S. (2015) Antibiotic resistance and virulence potentials of Shiga toxin-producing $E$. coli isolates from raw meats of slaughterhouses and retail markets in Korea. J. Microbiol. Biotechnol., 25(9): 1460-1466.

22. Ray, B., editor. (2004) Fundamental Food Microbiology. CRC Press, Boca Raton, Florida.

23. Ewers, C., Janssen, T., Kiessling, S., Philipp, H.C. and Wieler, L.H. (2004) Molecular epidemiology of avian pathogenic Escherichia coli (APEC) isolated from coli septicemia in poultry. Vet. Microbiol., 104: 91-101.

24. Pannuch, M., Sirikaew, S., Nakaguchi, Y., Nishibuchi, M. and Sukhumungoon, P. (2014) Quantification of enter pathogenic Escherichia coli from retailed meats. Int. Food Res. J., 21(2): 547-551.

25. Momtaz, H. and Jamshidi, A. (2013) Shiga toxin-producing Escherichia coli isolated from chicken meat in Iran: Serogroups, virulence factors, and antimicrobial resistance properties. Poult. Sci., 92: 1305-1313.

26. Schmidt, H., Beutin L. and Karch, H. (1995) Molecular analysis of the plasmid-encoded hemolysin of Escherichia coli O157:H7 strain EDL 933. Infect. Immun., 63: 1055-1061.

27. Mbanga, J., Ncube, V. and Magumura, A. (2016) Detection of extended spectrum $\beta$-lactamase producing Escherichia coli in retail chicken meat and humans in Bulawayo, Zimbabwe. Am. J. Res. Commun., 4(9): 190-207.

28. Kim, T.E., Jeong, Y.W., Cho, S., Kim, S.J. and Kwon, H.J. (2007) Chronological study of antibiotic resistances and their relevant genes in Korean avian pathogenic Escherichia coli isolates. J. Clin. Microbiol., 45: 3309-3315.

29. Bhoomika, B., Shakya, S, Patyal, A. and Gade, NE (2016) Occurrence and characteristics of extended-spectrum $\beta$-lactamases producing Escherichia coli in foods of animal origin and human clinical samples in Chhattisgarh, India. Vet. World, 9: 996-1000.

\section{$* * * * * * * *$}

